\title{
Correction to: A role for mast cells and mast cell tryptase in driving neutrophil recruitment in LPS-induced lung inflammation via protease-activated receptor 2 in mice
}

\author{
Aline Dias de Almeida ${ }^{1}$ - Irismara Sousa Silva ${ }^{1}$. Weslley Fernandes-Braga ${ }^{2}$ - Antônio Carlos Melo LimaFilho ${ }^{3}$. \\ Rodrigo Machado Florentino ${ }^{3}$. Ayslan Barra ${ }^{1}$ - Luciana de Oliveira Andrade L M. Fátima Leite $^{3}$. \\ Geovanni Dantas Cassali ${ }^{5}$. André Klein ${ }^{1}$ (D)
}

Published online: 7 August 2020

(c) Springer Nature Switzerland AG 2020

\section{Correction to: Inflammation Research https://doi.org/10.1007/s00011-020-01376-4}

In the original publication, fifth author name was incorrectly published as R odrigo Machado Florentino. The correct name should read as "Rodrigo Machado Florentino".

Publisher's Note Springer Nature remains neutral with regard to jurisdictional claims in published maps and institutional affiliations.

The original article can be found online at https://doi.org/10.1007/ s00011-020-01376-4.

\section{André Klein}

klein@ufmg.br

1 Laboratory of Pain and Inflammation, Department of Pharmacology, Institute of Biological Sciences, Federal University of Minas Gerais (UFMG), Av. Presidente Antônio Carlos, 6627, Pampulha, Belo Horizonte, Minas Gerais 31270-010, Brazil

2 Department of Biochemistry and Immunology, Institute of Biological Sciences, Universidade Federal de Minas Gerais, Belo Horizonte, Minas Gerais, Brazil

3 Department of Physiology and Biophysics, Institute of Biological Sciences, Universidade Federal de Minas Gerais, Belo Horizonte, Minas Gerais, Brazil

4 Department of Morphology, Institute of Biological Sciences, Universidade Federal de Minas Gerais, Belo Horizonte, Minas Gerais, Brazil

5 Department of Pathology, Institute of Biological Sciences, Universidade Federal de Minas Gerais, Belo Horizonte, Minas Gerais, Brazil 